\title{
Genealogi Stigma Sosial Terhadap Pasien Covid 19
}

Oleh:

\author{
Andi Agustang \\ andi.agustang@unm.ac.id \\ Indah Ainun Mutiara \\ indahainun@unismuh.ac.id \\ Andi Asrifan \\ andiasrifan@gmail.com
}

\section{Pendahuluan}

Penghujung akhir tahun 2019 gelombang besar menghantam cina tepatnya di provinsi wuhan yang membuat Negara tirai bambu tersebut mengalami kepanikan karena hantaman tersebut. Gelombang yang menghantam tiba - tiba itu bernama virus corona covid 19 yang menelan korban hingga puluhan ribu jiwa. Tak berbatas waktu yang lama, akhirnya wabah itu sampai ke Indonesia. Pandemi yang terkenal dengan sebutan Covid 19 ini mulai masuk di Indonesia pada awal Maret. pemerintah pusat segera mengambil langkah dan mengumumkan akan kasus covid - 19 yang sudah ada di Indonesia.

Covid - 19 dengan cepat menyebar ke daerah - daerah yang lain dimulia dari DKI Jakarta lalu provinsi - provinsi lainnya. Termasuk hingga ke Sulawesi selatan yang tercatat hingga hari ini kamis, 16 April 2020 yang dikeluarkan oleh Koran online Tribun Timur menyebutkan sebanyak 271 positif, 23 orang meninggal 42 pasien sembuh dan 29 kasus baru.

Selain angka - angka mengenai jumlah pasien yang semakin banyak dan semakin membuat ketakutan - ketakutan bermunculan, ada hal lain yang mengancam dan bisa dilihat dengan pasti, yaitu stigma negatif terhadap pasien covid - 19. Stigma ini bahkan tidak hanya melekat saat menjadi pasien tetapi hingga saat pasien telah meninggal dunia, stigma itu masih dilekatkan. lalu bagaimana stigma itu muncul dan sangat kuat efeknya?

\section{Genealogi : Jalan Awal Penelusuran}

Genealogi dalam kacamata Foucault dalam (Ampy, 2013) adalah semacam sejarah yang melukiskan pembentukan macam-macam pengetahuan di dalamnya, baik tentang subjek maupun objek-objeknya, sejarah ini tidak memburu makna berdasarkan kontinuitas kausal yang mengarah pada suatu telos akan tetapi genealogi dalam prespektif Foucault merupakan pemutusan (rupture) kontinuitas sejarah, yang oleh Gadamer disebut Wirkungsgeschichte (sejarah yang efektif) atau sejarah adalah masa kini.

Genealogi Foucault sejatinya berorientasi untuk menemukan awal proses terbentuknya pengetahuan atau episteme yang bisa terjadi kapan saja, termasuk dalam masa pandemi Covid 19 saat ini. Genealogi Foucault tidaklah kemudian bertujuan utnuk menelusuri asal muasal seperti yang dilakukan oleh arkeologi serta tidak berniat untuk kembali kepada masa yang lalu. 
Sederhananya, Genealogi yang dikembangkan Foucault adalah bukan semata mata sebuah teori tetapi lebih sebagai paradigma atau sebuah model perspektif untuk merekonstruksi serta mempertanyakan pengetahuan atau episteme, praktik sosial dan diri manusia itu sendiri. hal ini diperlukan agar segala pengetahuan atau episteme manusia atau masyarakat bisa diketahuan unsur - unsur pembentuknya.

\section{Stigma Sosial : Sebuah Defenisi}

Suatu keniscayaan bahwa manusia adalah mahluk biologis sekaligus mahluk social yang seperti dua sisi mata uang dan saling berkaitan. secara biologis, manusia tersusun atas struktur - struktur tubuh yang memiliki fungsi masing-masing dan saling menunjang dalam segi manfaat. secara social, manusia adalah mahluk yang membangun interaksi kesesama manusia atau kelompok lainnya. ketika fungsi biologis tidak berfungsi dengan baik, maka peran social akan menunjangnya. ketika seseorang sedang sakit secara biologis atau medis maka peran social akan muncul seperti saling membantu atau menjenguk.

Namun ada keterhubungan antara biologis dan social ini tidaklah selamanya sesuai dengan harapan. dalam banyak kasus ketika penyakit biologis itu dianggap menular dan membahayakan orang lain, maka yang muncul adalah prilaku social yang sifatnya stigmasasi akan berkembang. contoh kasus saat ini adalah pasien covid - 19 yang kemudian dianggap sebuah masalah ditengah masyarakat selain penyebabaran covid - 19 itu sendiri.

Menurut Goffman (1968) stigma adalah bentuk atribut fisik dan sosial yang mengurangi identitas social seseorang, mendiskualifikasi orang itu dari penerimaan seseorang. Sukmawati (2014) juga mengutip Goffman yang menyatakan bahwa stigma merupakan atribut yang mendiskreditkan seseorang sebagai manusia yang "tidak sama seutuhnya" dengan manusia normal dan biasanya menuju ke hal yang negatif. Defenisi goffman menyiratkan akan sebuah identitas yang tergerus karena tidak lagi sama secara fisik dengan yang lainnya. Identitas menurut Amartya Sen ( 2007 ) juga bisa memicu pembunuhan dan membuat orang mati sia - sia. Dalam hal covid - 19, identitas yang berbeda (sehat) kemudian membunuh identitas yang lainnya (sakit) dengan dalih dan dalil keselamatan orang banyak. Goffman (dalam Scheid \& Brown, 2010) membagi tiga tipe perihal stigma yaitu : 1) Stigma yang berhubungan dengan kecacatan pada tubuh seseorang (cacat fisik) 2) Stigma yang berhubungan dengan kerusakan-kerusakan karakter individu, misal homosexuality. 3) Stigma yang berhubungan dengan ras, bangsa dan agama.

Menurut Goffman dalam (Ritzer : 2012) ada berbagai penyebab terjadinya stigma antara lain sebagai berikut :

a. Takut,

Dilansir Akurat Health dari Boldsky, Stigma Sosial yang terkait dengan Covid - 19 didasarkan pada tiga faktor : Penyakit Virus Corona baru dan tidak dikenal, takut akan penyakit yang tidak diketahui itu, dan mudah menghubungkan ketakutan ini dengan 'orang lain'.

Hal - hal yang berhubungan dengan keselamatan fisik selalu membuat kekuatan ketakutan itu semakin besar apa lagi covid - 19 tergolong baru didengar bagi masyarakat awam dan secara umum ketakutan paling dasar adalah takut bila nantinya akan tertular.

b. Tidak menarik.

Memiliki kondisi yang berbeda secara umum atau tidak menarik memang akan membuat stigma lahir disebabkan perbedaan fisik yang tidak mengikuti pola 
umum atau kebanyakan. Dalam hal ini, tidak menarik itu berada pada titik sebagai atau pernah menjadi pasien covid - 19 dan orang - orang yang sehat tetapi takut tertular.

c. Kegelisahan.

Berbeda dengan orang lain secara fisik maupun medis seperti label pasien covid 19 akan membuat situasi psikologis yang tidak nyaman dan membuat pasien covid - 19 pun dinyatakan telah sembuh tetap merasa tidak tahu harus melakukan apa dihadapan orang - orang yang sehat sedari awal

d. Asosiasi. Stigma asosiasi cenderung disamakan dengan stigma simbolik. Ini disebabkan karena asumsi yang terbangun di masyarakat semisal bahwa covid 19 ini terjadi karena perilaku tidak sehat dari si individu atau balasan Tuhan atas dosa - dosa yang telah dia lakukan.

e. Kebijakan atau Undang-undang

Point ini lebih menyoal tentang regulasi yang mesti ditetapkan oleh penentu kebijakan yang tentunya membuat pasien covid - 19 menjadi nyaman dan akhirnya bisa diterima kembali dalam masyarakat. Hal ini juga dapat terlihat dari fasilitas yang diperuntukkan untuk pasien covid - 19 yang khusus dan tidak digabung dengan fasilitas penyakit menular lainnya.

f. Kurangnya kerahasiaan

Dalam hal covid - 19 ini, kerahasian hasil tes dari masyarakat haruslah terjaga dengan baik. Dalam artian jika hasil tes tersebut telah diteliti dengan baik maka informasi itu harus dibuka kepublik. Dengan catatan adalah data tes itu memang falid.

Pendapat lain juga dikemukan oleh Surgeon General Satcher's (dalam Teresa, 2010) yang menyatakan stigma adalah kejadian atau fenomena yang menghalangi seseorang untuk mendapatkan perhatian, mengurangi seseorang untuk memperoleh peluang dan interaksi sosial. Fenomena tersebut adalah bentuk negatif dikarenakan gagal paham atas sebuah kondisi. Stigma negatif ini menurut Castro dan Farmer (2005) dapat mendorong seseorang untuk mempunyai prasangka pemikiran, perilaku, dan atau tindakan oleh pihak pemerintah, masyarakat, pemberi kerja, penyedian layanan kesehatan, teman sekerja, para teman dan keluarga.

Stigma yang berkembang pada kondisi saat ini adalah pemutusan interaksi sosial serta prasangka - prasangka buruk terhadap pasien covid - 19 berupa sumber penyakit atau penyebab kematian seseorang. Stigma inilah kemudia yang berkembang sehingga menciptakan kepanikan ditengah masyarakat baik yang sehat - sehat saja maupun pasien covid -19 .

\section{Stigma Sosial : dari mana dan akan kemana}

Pandemi Covid 19 yang mulai merebak pada awal Maret di Indonesia direspon oleh pemerintah dengan cepat pun tanpa persiapan yang memadai. Sebelum pandemic tersebut sampai di Indonesia, candaan yang agak jumawa terkadang terdengar begitu lugas keluar dari mulut kemulut. dari iklim tropis Indonesia akan membuat virus itu mati dan bahkan dengan minum jahe maka virus itu akan hilang seketika. realitasnya kabar buruk itu mewujud dalam civid 19 sampai juga ke Indonesia.

Sedikit demi sedikit namun pasti, korban covid 19 semakin bertambah. dari satu provinsi melintasi provinsi lain, dari satu daerah memasuki daerah lain. masyarakat mulai panic, pemerintah dan organisasi keagamaan mengeluarkan himbauan agar masyarakat mengurangi aktivitas yang sifatnya mengumpulkan banyak orang. pesta pernikahan, rapat - rapat, shalat berjamaah dan shalat jum'at tak luput dalam maklumat 
tersebut. semua dilakukan untuk memotong rantai penyebaran covid 19. Namun masyarakat mengindahkan itu bahkan hingga pasien sudah mencapai ribuan, masyarakat yang lain masih asyik dengan pola hidup seperti biasa.

Kemalangan terjadi ketika seseorang masuk dalam kategori ODP (orang dalam pantauan) atau PDP (Pasien dalam Pantauan) hingga pasien dinyatan positif dan perlu mendapatkan penanganan serius atau pasien kemudian meninggal dunia. Maka kepanikan dimasyarakat semakin menjadi - jadi ditambah dengan informasi yang tak jelas sumbernya semakin menambah masyarakat menjadi panik. Akhirnya stigma pun terbangun bagi masyarakat terhadap pasien covid 19 yang memandang mereka sebagai sumber bahaya yang mengancam orang banyak sementara si pasien dan keluarganya merasa bahwa penyakit yang dideranya merupakan suatu aib.

Kepanikan sosial ini membuat masyarakat membangun control yang ketat agar pandemic tersebut tidak menyebar luas. Malangnya kepanikan berupa control ketat itu bukan kepada virusnya tetapi juga kepada pasiennya. Akhirnya pengucilan, pengusiran bahkan penolakan mayat pasien covid 19 menjadi akumulasi kepanikan tersebut. Stigma yang terkonstruksi dari kepanikan tersebut membuat sebuah masalah sosial baru dalam masyarakat.

Crocker, dkk. (dalam Major \& O’Brien, 2005) berpendapat bahwa stigma terjadi karena individu memiliki beberapa atribut dan karakter dari identitas sosialnya namun akhirnya terjadi devaluasi pada konteks tertentu. Kondisi - kondisi tersebut dapat ditelusuri dengan komponen - komponen berikut :

\section{Informasi yang bias}

Saat kondisi menjadi chaos seperti saat ini maka komunikasi dan informasi dari pemerintah adalah hal yang paling penting untuk diketahui. Informasi yang dikeluarkan oleh pemerintah tentunya bukanlah sebatas informasi tentang angka - angka atau jumlah korban covid 19 dari hari perhari tetapi juga informasi akan langkah apa yang mesti dilakukan agar kondisi ini tidak memburuk.

Edukasi yang menyeluruh dan simpatik semestinya dilakukan dengan cepat dan tepat sehingga tidak terjadi kepanikan dan stigma dalam masyarakat. Pemerintah sebagi pemegang otoritatif informasi tidaklah kemudian mengeluarkan informasi yang bias serta multitafsir oleh masyarakat. Ketegasan dengan tetap bersandar pada kearifan lokal adalah salah satu cara pemutus mata rantai covid - 19 ini.

Informasi pemerintah yang bias juga berupa istilah - istilah yang digunakan oleh pemerintah yang berhubungan dengan covid 19 seperti ODP (orang dalam pengawasan), PDP (pasien dalam Pengawasan). Bagi masyarakat awam, ketika seseorang sudah dikategorikan positif, maka ODP dan PDP tak ada bedanya, pesien tetap orang yang distigmasisasi sebagai sumber penyakit bagi yang lain sehingga perlu dijauhi. Edukasi akan informasi ini yang tidak sampai pada masyarakat sehingga paradigm itu terbangun dan berujung penolakan secara fisik dan psikologis.

\section{Kegagalan edukasi}

Edukasi informasi yang beredar sekarang ini adalah benteng paling tepat kepada masyarakat agar tidak lagi terjadi hal - hal yang sifatnya negatif. Edukasi ini juga semata - mata kepada masyarakat yang belum terpapar covid 19 tetapi juga untuk pasien yang masuk kategori ODP atau PDP. Karena jangan sampai seperti yang dikatakan Heddy (2012) terjadi kesalahpahaman atau ketidakmengertian pihak pnolong mengenai pandangan dan tindakan antara dua pihak tersebut. Artinya,baik dari pihak penolong (Tenaga Medis) dan pasien terjadi kesalahpahaman dalam mengatasi kondisi 
tersbut.

Perlu dipahami bahwa penerimaan masyarakat akan bencan ini berbeda - beda sehingga proses edukasinya juga mesti berbeda. Secara umum ketakutan terbesar masyarakat bukan soal kelaparan tetapi adalah kematian. Sehingga angka - angka pemerintah perihal pasien yang meninggal perlu dibarengi dengan edukasi yang sifatnya solutif, bukan malah membuat keguncangan psikologis bagi masyarakat. Sehingga edukasi ini mesti dimulai dari tenaga medis lalu kepada masyarakat yang kemudian dievaluasi kembali oleh pemerintah sebagai masukan dari kekurangan proses yang telah dilakukan.

\section{Media Sosial}

Media sosial adalah alat yang paling efektif dalam membentuk opini public dan tidak memakan banyak waktu dan tenaga. Media sosial semestinya digunakan dengan cerdas serta membangun, namun kadan - kadang karena kepanikan maka media sosial menjadi penyebar berita hoax yang tak mendidik. Control ketat dari pemerintah akan penyebaran berita - berita juga lemah sehingga orang - orang dengan bebas menyebarkan berita - berita yang sifatnya lebih banyak informasi yang menakutkan. Media sosial yang tidak terkontrol akan menciptakan "komunikasi dan informasi berkembang tanpa kendali, yang melampaui alam, sifat dan tujuan komunikasi itu sendiri (hyper communication), sehingga menciptakan semacam kegalauan komunikasi dan kegalauan informasi” (Yasraf :2011)

Bergerak dengan pasti, informasi hoax dari media sosial yang ditelan mentah mentah oleh masyarakat kemudian merekonstruksi pandangan akan pasein covid- 19 . Berita akan kecepatan virus ini menyebar atau berpindah membuat masyarakat baik perorangan atau perkelompok menerepkan tanda bahaya berupa penarikan garis fisik untuk tidak berhubungan lalu menolak dan mengucilkan.

Media sosial yang tidak terkontrol juga memberikan sumbangan ketakutan kepada masyarakat. Ketakutan yang berwujud stigma tersebut karena belum ditemukannya obat dari covid - 19 ini serta ketidak pedulian oleh pengguna media sosial akan adanya pemikiran dan ketakutan serta pikiran moril pembaca tentang covid -19 ini.

Senada dengan pernyataan Baudrillard dalam Yasraf (2011) bahwa penggembungan informasi telah menyebabkan informasi tidak dapat lagi dicerna pesannya, ditemukan nilai gunanya, ditafsirkan maknanya, dicari hikmanya pada masyarakat. Di dalam masyarakat yang gemuk (obesity) apa pun diriset, disimpan, direkam, ditulis, deprogram, dimemorikan, dikasetkan, didigitalkan, disiarkan, dipublikasikan tanpa peduli dengan tujuan, fungsi dan kegunaannya dalam rangka peningkatan kualitas manusia - inilah banalitas informasi.

Berdasarkan pernyataan tersebut, media sosial tidak lagi berfungsi sebagai alat kesimbangan hidup yang berperan lewat penyebaran informasi. Orang - orang menyebarkan informasi tanpa melihat efek sosialnya seperti informasi yang bisa menciptakan kebencian atau ketakutan ditengah masyarakat.

\section{Egosentris}

Kehadiran covid - 19 selain efek fisik ternyata juga membuka tabir betapa ego sebenarnya dapat terlihat dengan jelas saat ini. Orang - orang disekitar pasien covid 19 menampakkan ketakutan yang sangat besar yang hingga akhirnya melakukan langkah diskwalifakasi atas kehadiran seseorang termasuk identitas seseorang. Ego itu 
membuat sebuah pandangan yang saling berkaitan dan berkesimpulan bahwa pasien covid 19 adalah sebauh cacat yang harus diamputasi dalam masyarakat agar tidak menyebar.

Ke "aku"an ini dipupuk dan ditumbuhkan lalu disebarkan kepada orang lain yang akhirnya membentuk pemahaman kolektif. Mufakat yang tidak didasari dengan keilmuan yang cukup bermuara pada penolakan pasien covid - 19 dan bahkan sampai pada penolakan jenasah pasien covid - 19. Dan yang memiriskan adalah keegoan masyarakat yang juga menyasar kepada para dokter atau perawat yang merupakan orang - orang yang paling sering bertemu dengan pasien covid - 19. Pada hal merekalah orang - orang yang paling memeliki peran penting dalam memberikan jaminan kesehatan kepada pasien covid - 19 .

Eliminasi empatik ini pernah dibuktikan memalui penelitian atau survey seperti yang diungkapkan Herni dkk (dalam INDUSTRY.co.id) yaitu survey yang dilaksanakan oleh peneliti dari Fakultas Ilmu Keperawatan UI bekerjasama dengan Ikatan Perawat Kesehatan Jiwa Indonesia di awal April 2020 kepada 2050 perawat seIndonesia menunjukkan bahwa bahwa 140 perawat pernah merasa dipermalukan oleh orang lain karena statusnya sebagai perawat COVID-19 atau bertugas di RS tempat penanganan COVID-19.

Lebih lanjut dari penelitian ditemukan bahwa dalam survey ini menunjukkan sekitar 135 perawat pernah diminta meninggalkan tempat tinggalnya. Bentuk nyata penolakan yang dirasakan antara lain, ancaman pengusiran (66 responden), orang-orang disekitar menghindar dengan menutup pagar rumah/pintu mereka ketika melihat perawat (160 responden), dan masyarakat ikut menjauhi keluarga perawat (71 responden).

Berdasarkan data tersebut terlihat dengan jelas bahwa masyarakat memang menciptakan tembok pemisah akan diri mereka secara sosial. Tetapi Egosentris tersebut tidak melulu dilakukan oleh pihak yang sehat - sehat saja dalam tema ini. Tetapi juga bisa dilakukan oleh pasien covid - 19. Hal ini bisa dilihat dari pernyataan goffman yang disebut sebagai self indentity atau ego identity yaitu perasaan subjektif seseorang atau situasi yang dialami dan kelangsungan serta karakternya sendiri terpisah dari personal indentity atau dengan kata lain Goffman berpandangan bahwa individu merekonstruksi sebuah image atas dirinya seperti apa yang dikonstruksi dan diidentifikasi oleh orang lain, walaupun ia memilki kebebasan pada bagaimana ia mengindentifikasi dirinya dalam keseharian (pratikno,2010). Artinya pasien covid - 19 juga membangun jarak dengan masyarakat lain karena merasa sebagai sumber penyakit yang dimana itu berasal dari asumsi - asumsi masyarakat yang gagal secara edukasi.

Egosentris ini memang adalah hal normal ketika jaminan keselamatan terancam maka langkah manusiawi adalah bertahan dengan segala cara. Namun dalam kondisi yang seperti ini adalah hal penting untuk mengorbankan ke 'aku'an itu. Simpatik maupun empati akan tidak memilki fungsi ketika kondisi sosial maupun pribadi diselimuti oleh egosentris yang sangat diskriminatif terhadap perbedaan kondisi fisik dan sosial.

Stigma sosial yang terbangun dalam kasus ini adalah bangunan pengetahuan masyarakat yang terjadi karena hal - hal di atas tersebut. Geneologi stigma sosial akan pasien covid - 19 ini sekali lagi dapat ditelusuri dengan pola - pola seperti yang telah dipaparkan di atas. Ketakukan, informasi yang bias, kegagalan edukasi, sosial media yang lebih banyak menakut -nakuti dan egosentris yang meniadakan simpatik dan empati menjadi utuh dalam sebuah pandangan lalu berakhir pada penolakan, pengucilan 
dan pengusiran kepada pasien covid - 19. Hal inilah yang lebih menakutkan dari efek biologis covid - 19 karena ini akan tertanam lama dalam ingatan masyarakat.

Efek lain yang ditimbulkan adalah bagi orang - orang yang memiliki gejala covid - 19 yang berupa dapat memaksa orang yang sakit untuk menyembunyikan penyakitnya untuk menghindari diskriminasi, membuat seseorang mencegah untuk mencari penindakan medis sesegera mungkin dan juga dapat mencegah orang untuk menumbuhkan perilaku hidup sehat. Stigma sosial memang memiliki kekuatan yang besar dalam mengubah pandangan seseorang.

Stigma sosial tersebut mengambil alih kehidupan yang sedari awal terbangun dasar penyatuan atai integrasi kini terpecah berai. Hal ini merupakan sebuah separation atau pemisahan "kita" (sebagai pihak yang tidak memiliki stigma atau pemberi stigma) dengan "mereka" (kelompok yang mendapatka stigma). Hubungan label dengan atribut negatif akan menjadi suatu pembenaran ketika individu yang dilabel percaya bahwa dirinya memang berbeda sehingga hal tersebut dapat dikatakan bahwa proses pemberian stereotip berhasil (Link \& Phelan dalam Scheid \& Brown, 2010).

Hal yang menjadi penting kini adalah jalan keluar dari stigma - stigma yang terlanjur berkembang tersebut agar kondisi masyarakat secara sosiologis dan psikologi kembali normal sehingga keadaan ini segera bisa dapat teratasi. Yaitu dengan memperlajari segala informasi yang beredar serta mengedepankan simpati dan empati kepada orang - orang yang masuk kategori pasien covid - 19 tanpa perlu sangat takut dan menakut - nakuti orang lain. Serta memberikan kritik dan saran kepada penentu kebijakan agar semakin maksimal segala metode yang digunakan oleh pemerintah dalam memutus mata rantai penyebaran covid - 19 ini. Dan yang tidak kalah penting adalah ikut serta terlibat dalam segala keputusan yang telah ditentukan oleh pemerintah. 


\section{Daftar Pustaka}

A. Agustang, S Oruh (2017) Factors Affecting Of Heropnam Of Mental Disorders In Dadi Regional Hospital In South Sulawesi Province, Jurnal Man In India pp 233244

Amir Piliang, Yasraf (2011). Dunia Yang Dilipat : Tamasyah Melampaui Batas - Batas Kebudayaan,Bandung, Matahari

Ampy Kali, (2013). Diskursus Seksualitas, Yogyakarta, LEDALERO

Erving Goffman, ). (1968). Stigma: notes on the management of spoiled identity. Harmondsworth: Penguin

Castro, A. Farmer, P. (2005). Understanding And Addresing AIDS-Related Stigma : From Anthropological Theory To Clinical Practis In Haiti . Am J Public Health Jan. 95(1) 53-9.

Major, B., \& O'Brien, L. T. (2005). The social psychology of stigma. Annual review of psychology (56), 393. doi:10.1146/annurev.psych.56.091103.070137

Pratikno. Ari Agus, (2010). Stigmatisasi dan Perilaku Diskriminatif Pada Perempuan Bertato (Studi Deskriptif Mengenai Stigmatisasi dan Perilaku Diskriminatif pada perempuan Bertato ), Surabaya : Universitas Airlangga

Ritzer, George. 2012. Teori Sosiologi. Yogyakarta : Pustaka Pelajar

Scheid, T. L., \& Brown, T. N. (2010). A handbook for the study of mentak health social context, theories, and system second edition. New York: Cambridge,University Press.

Sen Amartya, ( 2006 ). Kekerasan dan Ilusi Tentang Kematian, Tangerang, PT Cipta Lintas Wacana.

Scheid, Teresa, L. B. T. N. (2010). A. Handbook For Study Of Mental Health Social Contexts. Theories and Systems Edition. New York : Cambridge University Press.

\section{Rujukan Inspirasi}

Ma'na, P., Agustang, A., Salusu, J., Ikhsan, A., \& Dirawan, G. D. (2015). Decision making strategic value based local wisdom Tongkonan North Toraja. Man India, 95(3), 633-639.

Upe, A., Salman, D., \& Agustang, A. (2019). The effects of the exploitation of natural resources towards risk society construction in Southeast Sulawesi Province, Indonesia. Journal of Degraded and Mining Lands Management, 6(2), 1587.

Awaru, A. O. T., Idris, R., \& Agustang, A. (2018, October). Sexual Education at High School Sinjai East. In 1st International Conference on Social Sciences (ICSS 2018). Atlantis Press.

Idris, M., Ramli, M., Agustang, A., \& Kesuma, A. I. (2015). Bureaucracy Ethics Based in Public Service Local Wisdom in Gowa. Mediterranean Journal of Social Sciences, 6(6 S4), 419-419.

Agustang, A., Pada, A. T., \& Bastiana, M. (2018, October). Social Interaction of Local Communities With Migrants and Changes in The Structure of Local Communities (Study on Plural Society in Makassar Industrial Area). In 1st International Conference on Social Sciences (ICSS 2018). Atlantis Press. 
Wardah, S., Salman, D., Agustang, A., \& Fahmid, I. M. (2017). The Contestation of Organic and Non-Organic Agricultural Knowledge in Sustainable Agriculture. Mediterranean Journal of Social Sciences, 8(2), 245-245.

Agustang, A. (2018). SIMBOLIKHAJI: Studi Deskriptif Analitik pada Orang Bugis. Al-Qalam, 15(2), 317-334.

Pannyiwi, R., Agustang, A., Kasnawi, T., Pada, A. T., Yani, A., \& Syam, S. (2020). Social Network for Drug Circulation in Sidenreng Rappang Regency, Indonesia. Systematic Reviews in Pharmacy, 11(9), 575-577.

Agustang, A., \& Soelthan, A. (2015). Analysis of the Inhibiting Factors of Transparency in the Implementation of Local Governance. Mediterranean Journal of Social Sciences, 6(6 S4), 464.

Nain, U., \& Agustang, A. (2020). Analysis On The Utilization Of Village Funds In Cash For Work Program In Bulukumba Regency, South Sulawesi Indonesia. International Journal of Advanced Science and Technology, 29(7s), 2811-2818.

Azis, F., Idris, R., \& Agustang, A. (2017). Involution Fisheries: Post-Study Model of National Program in Integrated Movement at Community Fishermen's Village Development Arungkeke, Jeneponto. Mediterranean Journal of Social Sciences, 8(1), 441.

Agustang, A. D. M. P., \& Nur, H. (2020). Konflik Mahasiswa Parang Tambung Universitas Negeri Makassar. Phinisi Integration Review, 3(1), 46-54.

Rasyid, R., Agustang, A., Maru, R., Agustang, A. T. P., \& Sudjud, S. (2020). PENYULUHAN PENCEGAHAN PENYALAHGUNAAN NARKOBA DI KALANGAN PELAJAR SMP NEGERI 6 DUAMPANUA KABUPATEN PINRANG. JMM (Jurnal Masyarakat Mandiri), 4(2), 116-123.

Rahmania, S., \& Agustang, A. (2017). PRESEPSI MAHASISWA FIK TERHADAP PENYIMPANGAN SEKSUAL LESBIAN (STUDI KASUS PADA MAHASISWA FIK UNM). JURNAL SOSIALISASI, 162-168.

Ashar, A., \& Agustang, A. (2020). Dampak Sosial Dana Desa Dalam Kesejahteraan Masyarakat Di Desa Kalola, Kecamatan Maniangpajo, Kabupaten Wajo. Jurnal Sosialisasi: Jurnal Hasil Pemikiran, Penelitian dan Pengembangan Keilmuan Sosiologi Pendidikan, (1), 19-25.

Yusuf, M., \& Agustang, A. (2020). DINAMIKA PERUBAHAN SOSIAL EKONOMI PADA MASYARAKAT KINDANG KABUPATEN BULUKUMBA. Jurnal Sosialisasi: Jurnal Hasil Pemikiran, Penelitian dan Pengembangan Keilmuan Sosiologi Pendidikan, (2), 31-37.

Fransina, M., \& Andi, A. (2019). THE ANALYSIS OF EXISTENCE OF MIGRATION IN THE CONTEXT OF BASUDARA COMMUNITY IN AMBON CITY, INDONESIA. Russian Journal of Agricultural and SocioEconomic Sciences, 94(10).

Usman, A., Agustang, A., Djalal, D., \& Annas, S. (2018, October). The Contribution Of Supporter Community In Maximizing Their Role For The Advancement Of Makassar Football Club (PSM). In 1st International Conference on Social Sciences (ICSS 2018). Atlantis Press.

Agustang, A., \& Oruh, S. Factors affecting of heropnam of mental disorders in Dadi Regional Hospital in South Sulawesi Province. Man In India, 97(11), 233-244.

Pratiwi, E. L., \& Agustang, A. (2018). PERSEPSI ORANGTUA SISWA TERHADAP TINDAKAN GURU DALAM MENDISIPLINKAN SISWA DI SMK YPKK LIMBUNG. JURNAL SOSIALISASI, 6-10. 
Asri, A., Kasnawi, T., \& Agustang, A. Actors' Social Tensions on Traditional Birth Attendants and Midwife Partnerships in Childbirth Assistance (Sociology of Health Study in Bulukumba Regency).

Bahri, S., Kasnawi, T., Agustang, A., \& Adam, A. (2017). Vegetarian Community Social Movement (Analysis of Health Sociology in Makassar). The Social Sciences, 12(10), 1824-1831.

Djalante, A., Agustang, A., Tahmir, S., \& Sahabuddin, J. A Disadvantaged Tribe in Bajoe Village, Bone Regency: A Phenomenological Research on Bajo Tribe's Social Life in Bone Regency, South Sulawesi.

Rahmawati, R., \& Agustang, A. (2018). PERBANDINGAN POLA ASUH ORANG TUA SISWA BERPRESTASI DENGAN SISWA YANG TIDAK BERPRESTASI DI SMA NEGERI 2 GOWA. JURNAL SOSIALISASI, 115119.

Agustang, A. (2018). PERAN WALI KELAS DALAM PENYELESAIAN KONFLIK ANTAR SISWA DI SMA NEGERI 1 PINRANG. JURNAL SOSIALISASI, 12-16.

Irnawaty, I., \& Agustang, A. (2019). SMARTPHONE ADDICTION PADA MAHASISWA PENDIDIKAN SOSIOLOGI FAKULTAS ILMU SOSIAL UNIVERSITAS NEGERI MAKASSAR. JURNAL SOSIALISASI, 41-46.

Zainuddin, M., \& Agustang, A. (2019). KONTROL SOSIAL ORANGTUA TERHADAP PENGGUNAAN SMARTPHONE PADA REMAJA (STUDI DI DESA GIRING-GIRING KECAMATAN BONTONMPO KABUPATEN GOWA. JURNAL SOSIALISASI, 68-73.

Sofyan, Y., \& Agustang, A. (2018). PENERAPAN MODEL PEMBELAJARAN KOOPERATIF TIPE NHT (NUMBERED HEADS TOGETHER) TERHADAP KEAKTIFAN BELAJAR SISWA KELAS XI IPS 1 SMAN 8 MAKASSAR. JURNAL SOSIALISASI, 158-165.

Agustang, A. (2018). PENERAPAN PUNISHMENT DALAM MEMBENTUK KARAKTER DISIPLIN SISWA DI SMA NEGERI 1 TAKALAR. JURNAL SOSIALISASI, 126-130.

Amiruddin, T. K., Agustang, A., \& Idris, R. (2014). RELIGIOUS CONVERSION IN MARRIED LIFE IN MAKASSAR, THE CASE OF CHRISTIANITY TO ISLAM. JOURNAL OF ACADEMIC RESEARCH, 6(6), 264.

Machmuddin, H., Agustang, A., Kahar, F., \& Bustan, N. (2015). IMPROVING THE QUALITY OF PRIMARY HEALTH SERVICES IN THE PERSPECTIVE OF PARTICIPATORY GOVERNANCE. International Journal of Academic Research, 7(1).

Agustang, A., \& Sahabuddin, J. (2020, October). MODEL KOLABORASI SOSIAL PENDIDIKAN KARAKTER DI SEKOLAH SWASTA KECAMATAN BISSAPPU KABUPATEN BANTAENG. In PROSIDING SEMINAR DAN DISKUSI PENDIDIKAN DASAR.

Astinah, A., Idris, R., \& Agustang, A. (2020). AGILE LEADERSHIP AND DIVORCE EDUCATION: STUDY ON WOMEN'S PERCEPTION. Humanities, 8(3), 323-330.

Muis, I., Agustang, A., \& Adam, A. (2020). Elderly Poverty: Social Demographic, Work Distribution, Problem Health \& Social Protection. Asian Journal of Social Sciences \& Humanities Vol, 9(1).

Agustang, A. (2020). Symbolic Violence towards Students in the Context of the Existence of the Stereotypical Frames of Lecturers and Students in the Higher 
Education System in Indonesia. PalArch's Journal of Archaeology of Egypt/Egyptology, 17(2), 249-258.

Asrifan, A. (2009). Using songs in teaching English language for the young learners. ParePare: unpublished.

Puasa, K., Asrifan, A., \& Chen, Y. (2017). Classroom Talk in Bilingual Class Interaction. Research in Pedagogy, 7(1), 106-121.

Nadirah, N., Tahir, M. H., \& Asrifan, A. (2019). THE ABILITY TO TRANSLATE ENGLISH PHRASES INTO INDONESIAN AND THE DIFFICULTIES FACED BY THE ELEVENTH GRADE STUDENTS OF SMAN 1 PANCARIJANG. JOURNAL OF ADVANCED ENGLISH STUDIES, 2(1), 41-46.

Apdy, A. P. R., \& Asrifan, A. (2019, April). The Chinese mime game in teaching vocabulary on EFL classroom. In PROCEEDINGS OF THE 65th TEFLIN INTERNATIONAL CONFERENCE (Vol. 65, No. 01).

Taslim, T., Asrifan, A., Chen, Y., \& Nurdania, N. R. (2019). CORRELATION BETWEEN STUDENT'S VOCABULARY MASTERY AND SPEAKING SKILL. JOURNAL OF ADVANCED ENGLISH STUDIES, 2(2), 65-76.

Muthmainnah, M., Asrifan, A., Al Yakin, A., \& Sahabuddin, C. (2019, April). The use of dictogloss technique on ELT classroom: An experiment study of students listening comprehension. In PROCEEDINGS OF THE 65th TEFLIN INTERNATIONAL CONFERENCE (Vol. 65, No. 01).

Mutmainnah, M., Azis, S., Maulidya, U., \& Asrifan, A. (2017). Glory Style in Mandar Song Lyrics: A study of Mandar Tribe in South Sulawesi, Indonesia. JOURNAL OF ADVANCES IN LINGUISTICS, 8(1), 1286-1291.

Asrifan, A., Rinantanti, Y., Tang, S., \& Nadirah, N. (2019). THE 3-DIMENSION PICTURES IN INCREASING THE STUDENTS ABILITY AND INTEREST TO WRITE DESCRIPTIVE COMPOSITION. JOURNAL OF ADVANCED ENGLISH STUDIES, 2(1), 19-30.

Asrifan, A., Nadira, N., \& Haedar, H. (2018). IMPROVING STUDENTS'READING COMPREHENSION OF DESCRIPTIVE TEXT THROUGH COLLABORATIVE MURDER. JOURNAL OF ADVANCED ENGLISH STUDIES, 1(2), 21-31.

Asrifan, A. (2015). Analysis of English Students' Learning Style in Bilingual Class. International Journal of Literature and Arts, 3(4), 34.

Farahdiba, S., \& Asrifan, A. (2016). Speaking Ability and Psychological Barriers of the Second Year Students of Hotel Department of SMKN 1 Sidenreng Kabupaten Sidrap in Speaking English. Asian EFL Journal, (89), 41.

Asrifan, A. (2012). Increasing the Students Ability to Write Descriptive Composition at SMP Negeri 13 Parepare by using the 3-Dimension Pictures.

Tang, S., Asrifan, A., Chen, Y., Haedar, H., \& Agussalim, M. (2019). THE HUMOR STORY IN TEACHING READING COMPREHENSION. JOURNAL OF ADVANCED ENGLISH STUDIES, 2(2), 77-87.

Nurwanti, N., Asrifan, A., \& Haedar, H. (2019). THE APPLICATION OF COOPERATIVE LEARNING: JIGSAW II TECHNIQUE IN IMPROVING STUDENTS'READING COMPREHENSION OF EXPOSITORY TEXT. JOURNAL OF ADVANCED ENGLISH STUDIES, 2(1), 31-40.

Asrifan, A. (2016). The Effectiveness of Think-Pair-Share Technique in Improving Studentsâ€ $€^{\mathbf{T M}}$ Speaking Ability and Interest. English Literature and Language Review, 2(3), 24-35. 
Asrifan, A., Muthmainnah, M., Al-Yakin, A., Sahabuddin, C., \& Haedar, H. (2018). THE CAUSE-EFFECT TECHNIQUE IN TEACHING RECOUNT WRITING. JOURNAL OF ADVANCED ENGLISH STUDIES, 1(2), 63-72.

Asrifan, A., Vargheese, K. J., Syamsu, T., \& Amir, M. (2020). ESP COURSE DESIGN: THE NEED ANALYSIS ON TOURISM DEPARTMENT IN INDONESIA VOCATIONAL HIGH SCHOOLS. JOURNAL OF ADVANCED ENGLISH STUDIES, 3(2), 69-77.

Asrifan, A., Ghofur, A., \& Azizah, N. (2020). Cheating Behavior in EFL Classroom (A Case Study at Elementary School in Sidenreng Rappang Regency). OKARA: Jurnal Bahasa dan Sastra, 14(2), 279-297.

Nadirah, N., Asrifan, A., Vargheese, K. J., \& Haedar, H. (2020). INTERACTIVE MULTIMEDIA IN EFL CLASSROOM: A STUDY OF TEACHING READING COMPREHENSION AT JUNIOR HIGH SCHOOL IN INDONESIA. JOURNAL OF ADVANCED ENGLISH STUDIES, 3(2), 131145.

Muthmainnah, A. R., Atmowardoyo, H., Salija, K., \& Asrifan, A. (2020). Literary Work as Teaching Materials: A Study of Students and Lecturers Needs Analysis. Solid State Technology, 63(5), 394-407.

Tilome, A. A., Agustang, A., Jasruddin, M. S., \& Asrifan, A. (2020). Social Exchange of Political Elites in the Regional Leader Election of Gorontalo Province, Indonesia. Solid State Technology, 63(5), 521-531.

Pacinongi, A., \& Asrifan, A. (2020). Bimbingan Pengawas Berkelanjutan dalam Mewujudkan Pendidikan Karakter Bangsa dalam Kegiatan Belajar Mengajar Penjaskes. Celebes Education Review, 2(1), 1-7.

Gunawan, G., \& Asrifan, A. (2020). Penerapan Kerja Kelompok Kegiatan MGMP Guru Ekonomi dalam Menyusun RPP untuk Meningkatkan Kompetensi Pedagogik. Celebes Education Review, 2(1), 31-36.

Yusuf, I., \& Asrifan, A. PENINGKATAN AKTIVITAS KOLABORASI PEMBELAJARAN FISIKA MELALUI PENDEKATAN STEM DENGAN PURWARUPA PADA SISWA KELAS XI IPA SMAN 5 YOGYAKARTA. Editorial Team, 32.

Al Yakin, A., Sahabuddin, C., Rahayu, A., Fitrah, N., \& Arifin, M. (2020). Political Celebrification and Electability: A Study of Political Phenomena Imaging in Election Polewali Mandar District, West Sulawesi, Indonesia. Solid State Technology, 63(5), 632-646.

Junaedah, S. B. T., \& Ahmad, M. A. (2020). The Outdoor Learning Modules Based on Traditional Games in Improving Prosocial Behaviour of Early Childhood. International Education Studies, 13(10).

Octaberlina, L. R., \& Muslimin, A. I. (2020). Efl students perspective towards online learning barriers and alternatives using moodle/google classroom during covid19 pandemic. International Journal of Higher Education, 9(6), 1-9.

Octaberlina, L. R., \& Anggarini, I. F. (2020). Teaching vocabulary through picture cards in Islamic Elementary School: a case study in Nida Suksa School, Thailand. Jurnal Madrasah, 13(1), 26-38.

Octaberlina, L. R. (2016). Plagiarism in English language theses in Indonesia. Jurnal Ilmu Pendidikan, 14(3).

Octaberlina, L. R., \& Anggarini, I. F. (2020). Teaching vocabulary through picture cards in Islamic Elementary School: a case study in Nida Suksa School, Thailand. Jurnal Madrasah, 13(1), 26-38. 
Asrifan, A., Zita, C. T., Vargheese, K. J., Syamsu, T., \& Amir, M. (2020). THE EFFECTS OF CALL (COMPUTER ASSISTED LANGUAGE LEARNING) TOWARD THE STUDENTS'ENGLISH ACHIEVEMENT AND ATTITUDE. JOURNAL OF ADVANCED ENGLISH STUDIES, 3(2), 94106.

Asrifan, A. (2021). ACADEMIC WRITING. LawArXiv. January, 2. https://doi.org/10.31228/osf.io/x2s7e

Asrifan, A. (2020). TUTORIAL PENGGUNAAN QUIZIZZ (www. quizizz. com) PADA PEMBELAJARAN. https://doi.org/10.31219/osf.io/kqnza

Asrifan, A. (2021). Abd Ghofur.“. THE USE OF READING CIRCLES IN INCREASING STUDENTS SPEAKING ABILITY AT THE ELEVENTH GRADE SMK NEGERI, 1. https://doi.org/10.31219/osf.io/8vjxy

Asrifan, A. (2020). Pandemic, Humanity and Education. https://doi.org/10.31219/osf.io/q2gpk

Asrifan, A. (2021). USING CAT AND MOUSE GAME TO IMPROVE STUDENT'S SPEAKING ABILITY AT THE ELEVENTH GRADE OF MA YMPI RAPPANG. https://doi.org/10.31219/osf.io/phtvn

Asrifan, A., \& Ghofur, A. (2021). THE USE OF READING CIRCLES IN INCREASING STUDENTS SPEAKING ABILITY AT THE ELEVENTH GRADE SMK NEGERI 1 PANCARIJANG. https://doi.org/10.31219/osf.io/8vjxy

Asrifan, A. (2021). Book Review: Halliday. 1989. Spoken and Written Language. Oxford University Press. https://doi.org/10.31219/osf.io/ej8tb

Asrifan, A., \& Ghofur, A. (2021). TALK, ACTION, SILENCE, INTERRUPTION AND THEIR IMPLICATIONS IN BUGINESE SOCIETY (SOPPENG REGENCY). https://doi.org/10.31219/osf.io/pv3ku

Asrifan, A. (2020). PENILAIAN BERBASIS ANDROID MENGGUNAKAN APLIKASI PLICKERS. https://doi.org/10.31219/osf.io/htreq

Sapulette, A. A., Agustang, A., \& Syukur, M. Actor Construction in the Frame of Diversity to Achieve Social Harmony in the Life of Tamilouw Village Society Seram Island-Maluku.

Amiruddin, T. K., Agustang, A., \& Idris, R. (2014). RELIGIOUS CONVERSION IN MARRIED LIFE IN MAKASSAR, THE CASE OF CHRISTIANITY TO ISLAM. JOURNAL OF ACADEMIC RESEARCH, 6(6), 264.

Machmuddin, H., Agustang, A., Kahar, F., \& Bustan, N. (2015). IMPROVING THE QUALITY OF PRIMARY HEALTH SERVICES IN THE PERSPECTIVE OF PARTICIPATORY GOVERNANCE. International Journal of Academic Research, 7(1).

Agustang, A., \& Sahabuddin, J. (2020, October). MODEL KOLABORASI SOSIAL PENDIDIKAN KARAKTER DI SEKOLAH SWASTA KECAMATAN BISSAPPU KABUPATEN BANTAENG. In PROSIDING SEMINAR DAN DISKUSI PENDIDIKAN DASAR.

Mutiara, I. A., Agustang, A., Adam, A., Upe, A., \& Equatora, M. A. (2020). The dynamics of prostitutes lives in metropolitan cities. Journal of Critical Reviews. https://doi. org/10.31838/jcr, 7, 165.

Haulussy, R. H., Najamuddin, I. R., \& Agustang, A. D. M. P. (2020). The sustainability of the Sasi Lola tradition and customary law (Case study in Masawoy Maluku, Indonesia). Intl J Sci Technol Res, 9(2), 5193-5195. 
Agustang, A. (2020). Symbolic Violence towards Students in the Context of the Existence of the Stereotypical Frames of Lecturers and Students in the Higher Education System in Indonesia. PalArch's Journal of Archaeology of Egypt/Egyptology, 17(2), 249-258.

Agustang, A. (2015). Dasar-Dasar Filsafat Penelitian Untuk Pengembangan Ilmu.

Agustang, A. T. P. Muh. Said, dan Rusman Rasyid. 2015. Perkembangan Peran Jender Dalam Prespektif Teori Androgini, 1-8.

Rasyid, R., Agustang, A., Agustang, A. T. P., Bastiana, B., \& Najamuddin, N. Analisis Faktor Yang Mempengaruhi Status Kemiskinan Rumah Tangga Pada Wilayah Central Bussiness District (CBD) di Kota Makassar. Majalah Geografi Indonesia, 34(1), 43-52.

Asmi, A. S., Kasnawi, M. T., Agustang, A., \& Yani, A. (2020). Sociocultural Transformation in Efforts to Reduce Mortality of Infants in Bone Regency, Indonesia. Systematic Reviews in Pharmacy, 11(10), 762-765.

Agustang, A. (2020, October). Social Actions of Galla Actors in the Kaemba Maros Traditional Village Community Sulawesi Selatan. In 3rd International Conference on Social Sciences (ICSS 2020) (pp. 748-753). Atlantis Press.

Agustang, A. (2020). The Symbolic Violence Towards Private School Students Through The Frame Stereotype In Bantaeng District Of Indonesia. Prosiding ICoISSE, 1(1), 578-588.

Ariani $^{1}$, A. I., Agustang, A., Adam, A., \& Alimsyah, S. (2020). INSTITUTIONAL FAILURES IN THE WORLD OF EDUCATION IN SCHOOLS FOR CHILDREN VICTIMS OF PARENTS. Asian Journal of Social Sciences \& Humanities Vol, 9, 2. 